\title{
Classification of the Musculocutaneous Nerve Fetuses
}

\author{
Clasificación del Nervio Musculocutáneo en Fetos
}

\author{
K. Kupsamy'; S. Ishwarkumar²; B. Z. De Gama ${ }^{1}$ \& P. Pillay ${ }^{1}$
}

KUPSAMY, K.; ISHWARKUMAR, S.; DE GAMA, B. Z. \& PILLAY, P. Classification of the musculocutaneous nerve in fetuses. Int. J. Morphol., 39(2):653-658, 2021.

SUMMARY: The musculocutaneous nerve is a terminating branch of lateral cord of the brachial plexus and is formed from spinal roots of $\mathrm{C} 5, \mathrm{C} 6$ and $\mathrm{C} 7$. The anatomical variations of the musculocutaneous nerve (MCN) are not common, literary reports have described the different course of the MCN in the arm, however very few fetal studies have been conducted on the variations of the MCN. Therefore, the aim of this study was to describe the course of the MCN in fetuses and document variations, if any. In this study, a sample size of twenty-five fetuses were bilaterally dissected $(n=50)$ using a stereomicroscope. The anatomy of the MCN was described using a classification system generated based on the findings of this study. Ethical clearance was obtained from Biomedical Research Ethics Committte (BE385/17). Type I (normal anatomy) of the MCN was found in 42/50 (84\%) of specimens in this study. This study found a few variations, viz. 1/50 (2\%) case of Type II (absent), 1/50 (2\%) Type III (communication between the MCN and MN, from the MN to the MCN), 4/50 (8\%) cases of Type IV (communication from the MCN to the MN) and 2/50 (4\%) cases of Type V (communication from the $\mathrm{MCN}$ to the $\mathrm{MN}$, where the MCN does not pierce the coracobrachialis muscle). Therefore, this study provides evidence of variations of the MCN in fetuses that may help surgeons in the interpretation of abnormal innervation patterns in the arm.

KEY WORDS: Musculocutaneous nerve; Fetal study; Classification; Variations.

\section{INTRODUCTION}

The anatomical structure of the brachial plexus is a highly developed network of neural structures, extending from the lower part of the side of the neck to the axillary region. Many variations can occur due to its intricacy in relation to other anatomical structures around it, thus, providing clinical and surgical information (Radunovic et al., 2013).

The musculocutaneous nerve is one of the terminating branches of the brachial plexus, arising from the lateral cord, containing fibres from spinal roots of C5, C6 and C7, thereafter terminating as the lateral cutaneous nerve of the forearm (Besleaga et al., 2010; Moore et al., 2014; Standring et al., 2016). In its course, it pierces the coracobrachialis muscle and descends laterally between the biceps brachii and brachialis muscles, thus innervating all the muscles in the anterior compartment of the arm. However,previous literature has found that the lateral cord pierced the coracobrachialis muscle and then divided into musculocutaneous nerve and the lateral root of median nerve (Le Minor, 1989). Later, it pierces the deep fascia above the elbow, lateral to the tendon of the biceps brachii and continues as the lateral cutaneous nerve of the forearm (Standring et al.).

In addition, the lateral cord gives off a branch, the lateral root of the median nerve, which is one of the major causes of the variations in the musculocutaneous nerve. Literature described communications between the musculocutaneous nerve and the median nerve, which is the most common form of variation when it comes to either the musculocutaneous nerve or the median nerve (Venieratos \& Anagnostopoulou, 1998; Choi et al., 2002; Loukas \& Aqueelah, 2005; Kwolczak-McGrath et al., 2008). In some cases, the musculocutaneous nerve was reported as absent (Fregnani et al., 2008). When this variation occurs, the lateral cord continues to become the median nerve giving innervation to the muscles surrounding it, thus innervating the muscles in the anterior compartment of the arm (Fregnani et $a l$.).Therefore, the aim of this study was to describe the course of the MCN in fetuses and document variations, if any.

\footnotetext{
${ }^{1}$ Department of Clinical Anatomy, School of Laboratory Medicine and Medical Sciences, College of Health Sciences, University of KwaZulu-Natal, Westville Campus, Private Bag X54001, Durban 4000, South Africa.

${ }^{2}$ Department of Human Anatomy and Physiology Faculty of Health Sciences, University of Johannesburg, Doornfontein Campus, P.O Box 524, Auckland Park, South Africa.
} 


\section{MATERIAL AND METHOD}

The present study was conducted at the Department of Clinical Anatomy, University of KwaZulu-Natal (Westville Campus). Twenty-five formalin preserved fetuses $(n=50)$ were bilaterally micro-dissected. The fetuses were placed in the supine position, a longitudinal incision in the anterior surface of the arm was made to expose brachial fascia and fat (Tank \& Boileau Grant, 2009). This was separated and removed making the underlying muscles visible (Tank \& Boileau Grant). The course of the MCN were traced through the plane of the loose connective tissue and the muscular branches of the MCN was observed to its terminal branch, lateral cutaneous nerve of the forearm (Tank \& Boileau Grant). This study generated its own classification scheme consisting of five types to incorporate all the variations found in the present study including the normal anatomy of MCN (Fig. 1). Ethical clearance was obtained from Biomedical Research Ethics Committee (BE385/17).

\section{RESULTS}

This study recorded the following results:

Type I. Incidence - 42 cases ( $84 \%$ ). Course and Branching Pattern - the MCN followed the standard anatomical course (Fig. 2).

Type II. Incidence - 1 Case (2\%). Course and Branching Pattern- the MCN was absent. The lateral cord fused with the medial root of the $\mathrm{MN}$, motor innovatory fibers of the anterior compartment of the arm originated directly from the upper part the MN. A branch from this union arose and then bifurcated to supply motor innervation to the Brachialis muscle. The lateral cutaneous nerve of the forearm was the terminating branch in this type (Fig. 3).

Type III. Incidence - 1 Case (2\%). Course and Branching Pattern- There was a communication between the MN and the MCN. This communication occurred from the MN

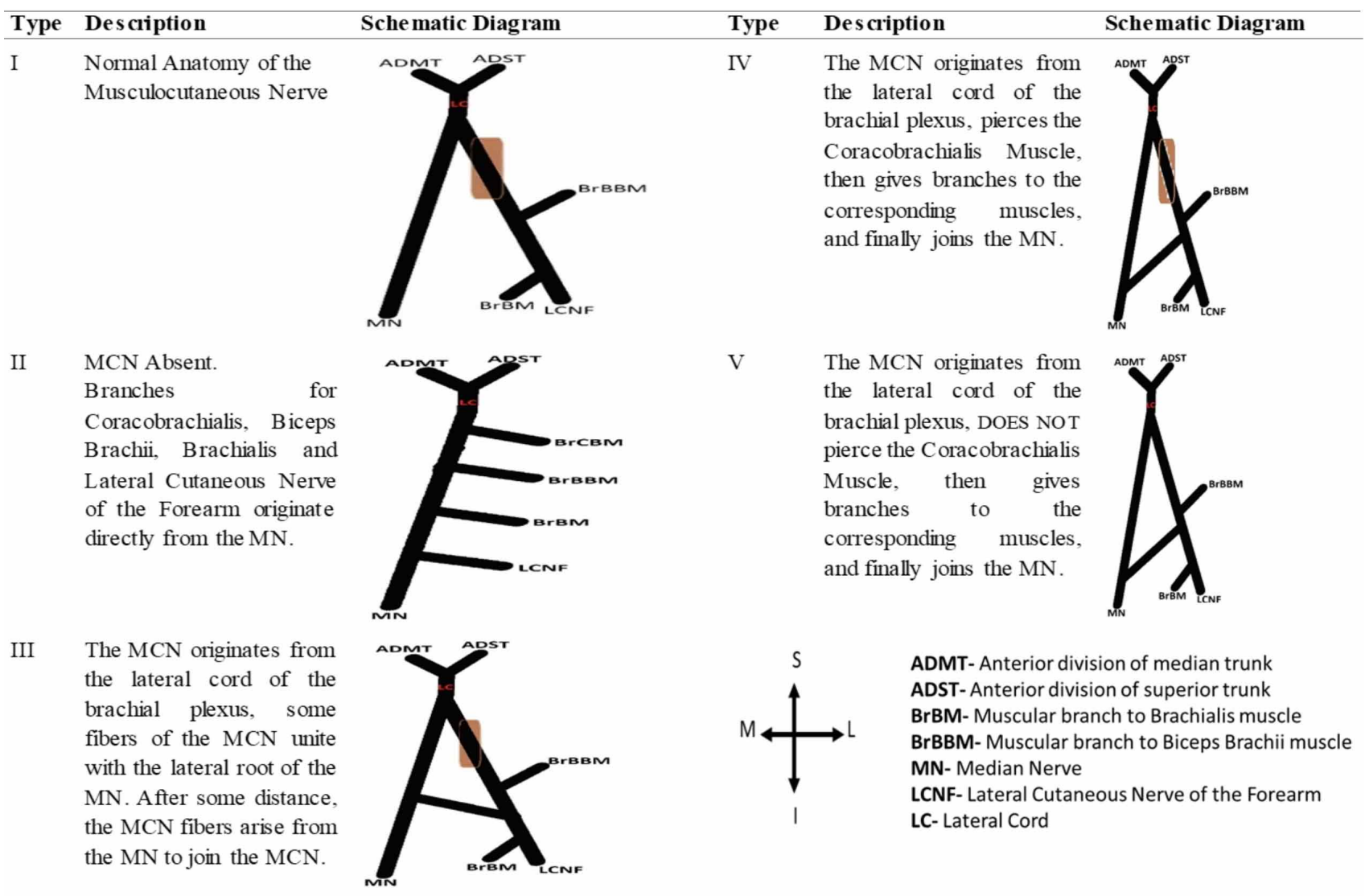

Fig. 1. Generated classification system of the course of the MCN (schema illustrating the right upper limb). 


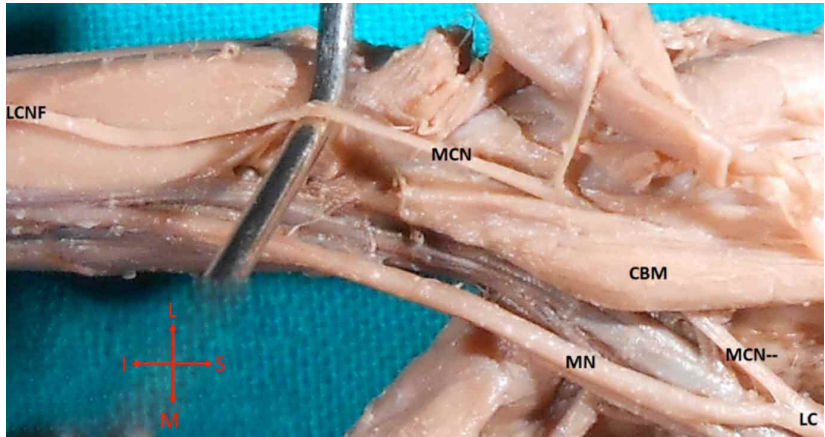

Fig. 2. Type I - Normal anatomy of right arm. MCN- MCN. CBMCoracobrachialis muscle, LCNF- Lateral cutaneous nerve of forearm, LC- Lateral cord, MN- Median nerve, MCNMusculocutaneous nerve, S- Superior, I- Inferior, M- Medial, LLateral.

joining the MCN. The MCN originated from the lateral cord of the brachial plexus, some fibers of the MCN joined with the lateral root of the MN and after some distance, arose from the MN to join the MCN (Fig. 4).

Type IV. Incidence -4 Cases $(8 \%)$ Course and Branching Pattern- A communication between the MCN and the MN, this classification is similar to type III but differed in that, the lateral root of the MN fibers, was united with the MCN and afterwards left the MCN to join back with the MN (Fig. 5). In Type IV, the MCN pierces the coracobrachialis muscle.

Type V. Incidence -2 Cases (4 \%). Course and Branching Pattern- the MCN originated from the lateral cord of the

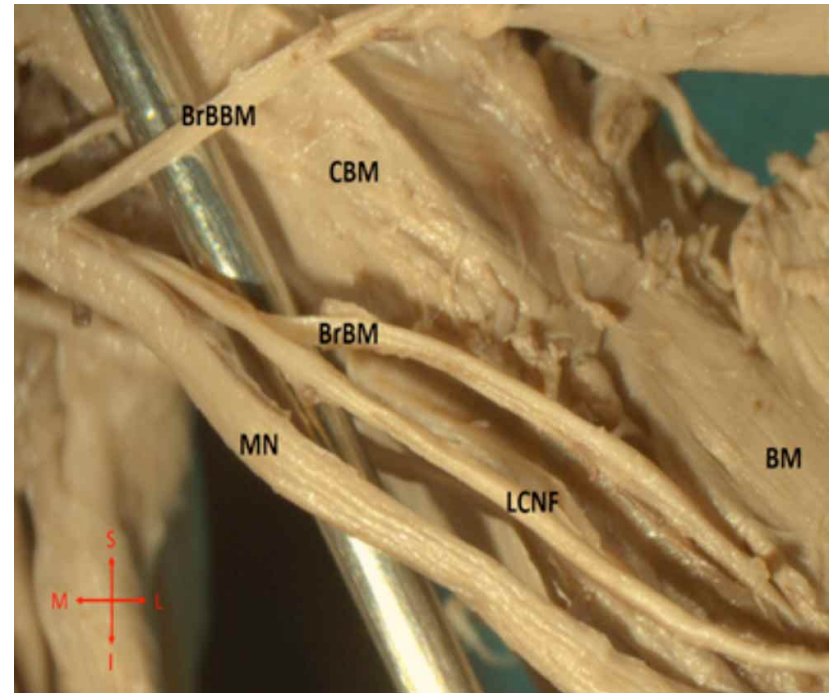

Fig. 3. Type II - Absent type. The lateral cord continued to become the MN which supplied the innervations that the MCN would have supplied. CBM- Coracobrachialis muscle, BrBBM- Muscular branch to biceps brachii muscle, BM- Brachialis muscle, BrBMMuscular branch to brachialis muscle, LCNF- Lateral cutaneous Nerve of forearm, MN- Median nerve, S- Superior, I- Inferior, MMedial, L- Lateral.

brachial plexus but did not pierce the coracobrachialis muscle it then gave branches to the biceps brachii muscle, brachialis muscle and lateral cutaneous nerve of the forearm also form a communication to the MN. This type is similar to Type IV except that in this type the MCN did not pierce the coracobrachialis muscle (Fig. 6).
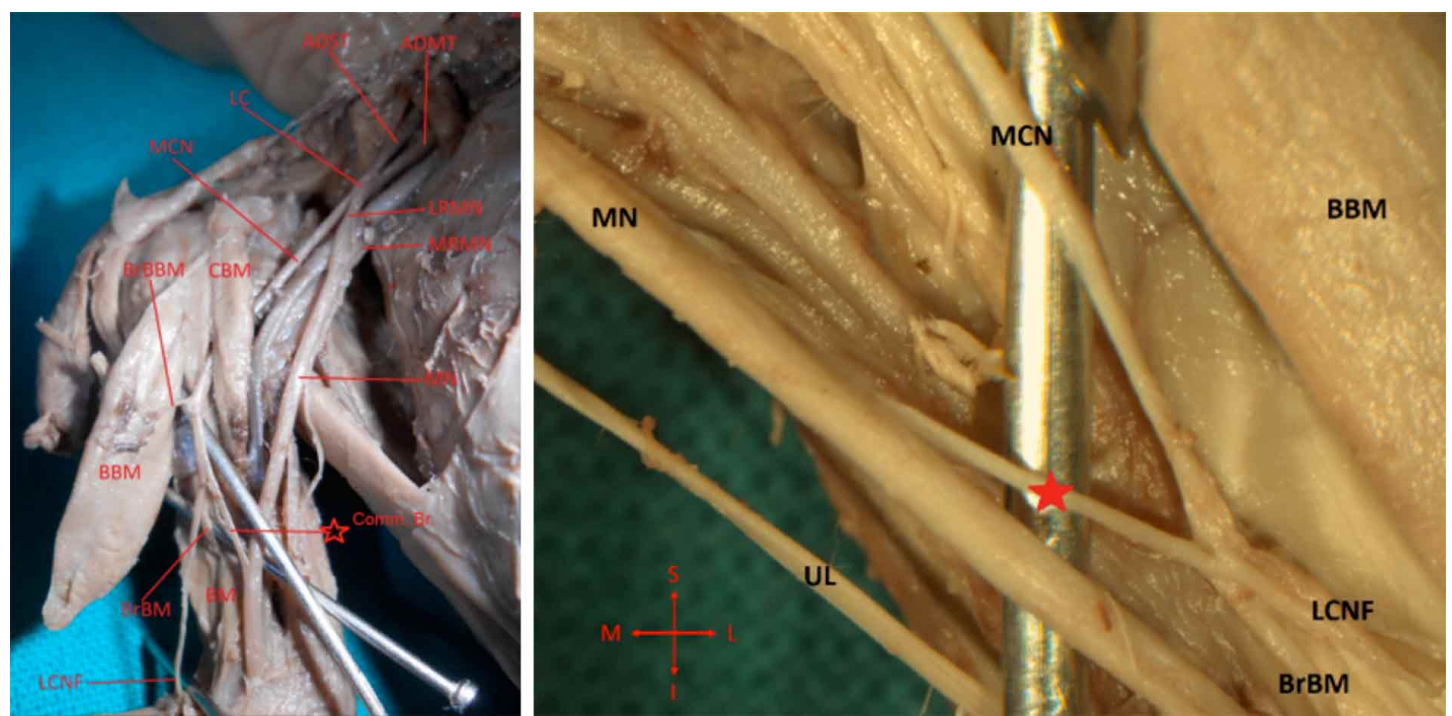

Fig. 4. TYPE III - Communicating branch from the MN to the MCN. BBM- Biceps brachii muscle, BrBM- Muscular branch to brachialis muscle, LCNF- Lateral cutaneous nerve of forearm, MN- Median nerve, MCN- Musculocutaneous nerve, UL- Ulnar nerve, S- Superior, I- Inferior, M- Medial, L- Lateral. 


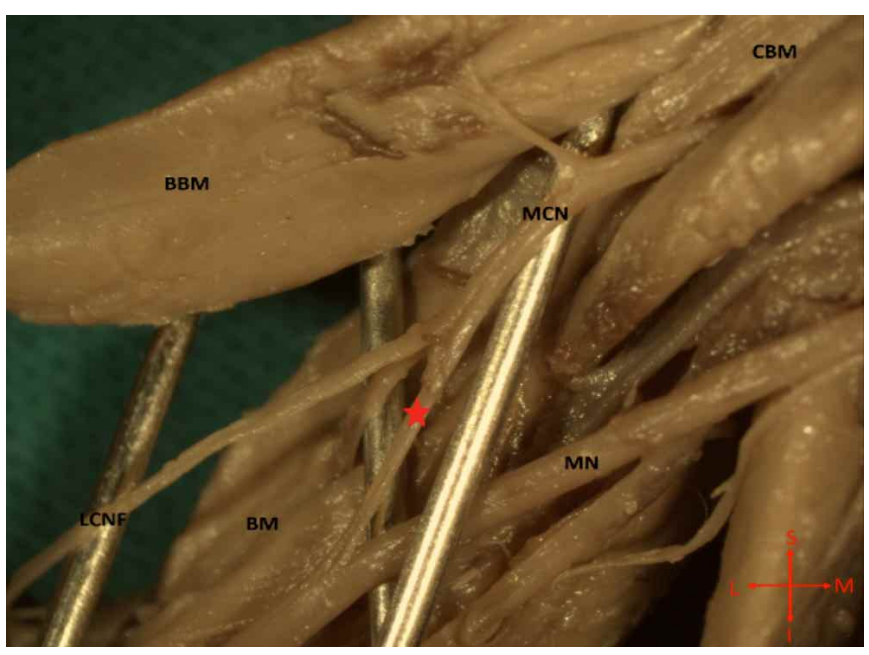

Fig.5. Type IV - Communicating branch from the MCN to the MN, MCN Pierces coracobrachialis muscle. CBM- Coracobrachialis muscle, BBM- Biceps brachii muscle, BM- Brachialis muscle, LCNF- Lateral cutaneous nerve of forearm, MN- Median nerve, MCNMusculocutaneous nerve, S- Superior, I- Inferior, M-Medial, L- Lateral.

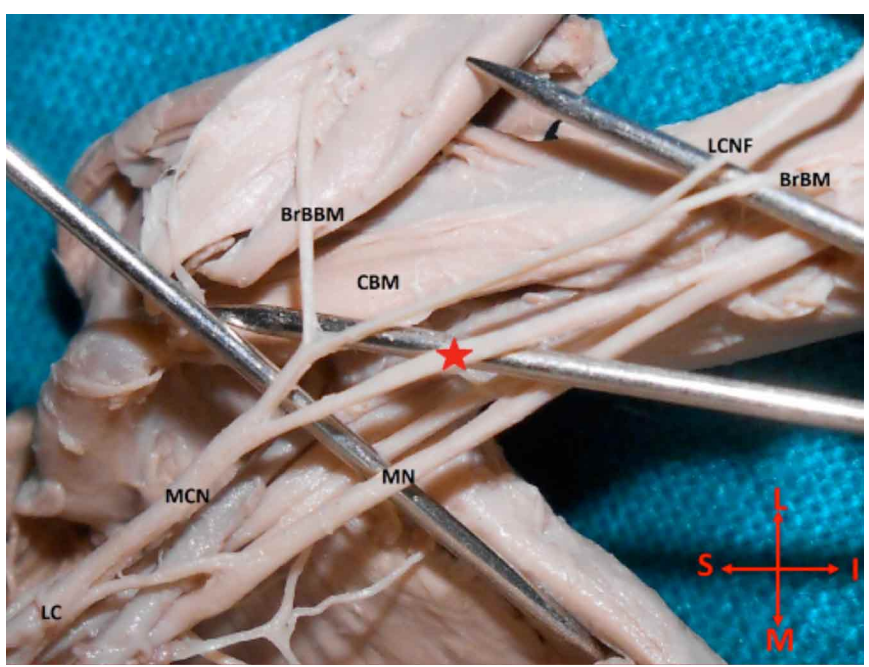

Fig. 6. Type V - Communicating branch from the MCN to the MN, MCN DOES NOT pierce Coracobrachialis muscle. CBM- Coracobrachialis muscle, BrBBM- Muscular branch to biceps brachii Muscle, BrBMMuscular branch to brachialis muscle, LCNF- Lateral cutaneous nerve of forearm, LC- Lateral cord, MN- Median nerve, S- Superior, I- Inferior, M- Medial, L- Lateral, MCN- Musculocutaneous nerve.

\section{DISCUSSION}

The general anatomy of musculocutaneous nerve $(\mathrm{MCN})$, as described by Standring et al., was observed in the majority of the sample (84\%) in the present study. This correlated to literary reports, who found that the majority of their sample size followed the normal anatomical course (Le Minor; Venieratos \& Anagnostopoulou; Choi et al.; Loukas \& Aqueelah; Krishnamurthy et al., 2007; Bhattarai \& Poudel, 2009; Guerri-
Guttenberg \& Ingolotti, 2009; Uysal et al., 2009; Kervancioglu et al., 2011; Leng et al., 2016).

The absence of the MCN (Type II) was first discovered by Le Minor in 3 cases. Venieratos \& Anagnostopoulou performed a study with a sample size of 158 upper limbs and there were no cases found where the MCN was absent. However, in other studies GuerriGuttenberg \& Ingolotti found the MCN to be absent in 4 $\%$ and Leng et al. in $3 \%$, these results are similar to the present study (Table I). In addition to Type II (absence of the MCN) some authors classified this as a fusion of the MCN and MN (Chauhan \& Roy, 2002; Guerri-Guttenberg \& Ingolotti). Whereas, others suggested that this is a variation of the lateral cord rather than a direct variation in the MCN (Chauhan \& Roy; Fazan et al., 2003; Aggarwal et al., 2010; Budhiraja et al., 2011).

In this study, the communicating branches are the most common and this correlated with previous studies (Table I).The communicating branches are typically understood as fibers that got crossed in the lateral cord. The lateral root of the $\mathrm{MN}$ fibers enters the $\mathrm{MCN}$ and joins the $\mathrm{MN}$ after some distance, and vice-versa, with the fibers of the MCN entering the lateral root of the MN continuing to become the MN, and it then ultimately leaves to enter back into the MCN (Prasada Rao \& Chaudhary, 2000). This was classified as Type III in the present study. In this study, Type III was found in $2 \%$ while, Le Minor found it in $6 \%$,when other authors did not clearly describe if the communication was from the $\mathrm{MN}$ to the $\mathrm{MCN}$ or viceverse. This information is vital because they are not the same as described above. Authors generalized them as the same and placed them both in the same category as a communication.

In Type IV, the coracobrachialis muscle is innervated by the MCN (Fig. 4). The occurrence of this communication between the MCN and MN was documented in literature, with the incidence ranging from $6 \%$ to $43 \%$. The following percentages were documented: $6 \%$ by Le Minor; $12 \%$ by Venieratos \& Anagnostopoulou; $19 \%$ by Choi et al.; $26 \%$ by Loukas \& Aqueelah; $20 \%$ by Chitra (2007); $6 \%$ by Bhattarai \& Poudel; $43 \%$ by Guerri-Guttenberg \& Ingolotti; $25 \%$ by Kervancioglu et $a l$. and $4 \%$ by Leng et al. These findings correlated with the findings of the present study (Table I).

The only difference between Type IV andType V is that the MCN does not pierce the coracobrachialis muscle. Venieratos \& Anagnostopoulou recorded 3 cases. Loukas \& Aqueelah recorded 11 cases and Chitra recorded 3 cases studies, while this study recorded only 2 cases. 
Table I. Various classifications of MCN documented in literature.

\begin{tabular}{|c|c|c|c|c|c|c|c|c|c|c|c|c|c|}
\hline Author & Specimen & $\begin{array}{l}\text { Sample } \\
\text { (n) }\end{array}$ & $\begin{array}{c}\text { Total } \\
\text { Incidence of } \\
\text { communications } \\
\text { (n) }\end{array}$ & $\begin{array}{l}\text { TYPE } 1 \\
\text { (n) }\end{array}$ & $\begin{array}{l}\text { TYPE } 1 \\
(\%)\end{array}$ & $\begin{array}{l}\text { TYPE } 2 \\
\text { (n) }\end{array}$ & $\begin{array}{l}\text { TYPE } 2 \\
(\%)\end{array}$ & $\begin{array}{l}\text { TYPE } 3 \\
\text { (n) }\end{array}$ & $\begin{array}{l}\text { TYPE } 3 \\
(\%)\end{array}$ & $\begin{array}{l}\text { TYPE } 4 \\
\text { (n) }\end{array}$ & $\begin{array}{c}\text { TYPE } 4 \\
(\%)\end{array}$ & $\begin{array}{l}\text { TYPE } 5 \\
\text { (n) }\end{array}$ & $\begin{array}{c}\text { TYPE } 5 \\
(\%)\end{array}$ \\
\hline Le Minor (1989) & Cadaver & 50 & 13 & 37 & 74 & 3 & 6 & 3 & 6 & 3 & 6 & 0 & 0 \\
\hline $\begin{array}{l}\text { Venieratos \& } \\
\text { Anagnostopoulou } \\
\text { (1998) }\end{array}$ & Cadaver & 158 & 22 & 136 & 86 & 0 & 0 & 0 & 0 & 19 & 12 & 3 & 2 \\
\hline Choi et al. (2002) & Cadaver & 276 & 73 & 203 & 74 & - & - & - & - & 53 & 19 & - & - \\
\hline $\begin{array}{l}\text { Loukas \& Aqueelah } \\
\text { (2005) }\end{array}$ & Cadaver & 258 & 119 & 139 & 54 & - & - & - & - & 66 & 26 & 11 & 4 \\
\hline Chitra (2007) & Cadaver & 50 & 13 & 37 & 74 & 0 & 0 & 0 & 0 & 10 & 20 & 3 & 6 \\
\hline $\begin{array}{l}\text { Krishnamurthy et al. } \\
\text { (2007) }\end{array}$ & Cadaver & 44 & 7 & 37 & 84 & - & - & - & - & - & - & - & - \\
\hline $\begin{array}{l}\text { B hattarai \& Poudel } \\
\text { (2009) }\end{array}$ & Cadavers & 32 & 2 & 30 & 94 & 0 & - & 0 & 0 & 2 & 6 & 0 & 0 \\
\hline $\begin{array}{l}\text { Guerri_Guttenberg } \\
\text { \& Ingolotti (2009) }\end{array}$ & $\begin{array}{c}\text { Cadaver } \\
\text { and Fetus }\end{array}$ & 56 & 32 & 24 & 43 & 2 & 5 & - & - & 24 & 43 & - & - \\
\hline $\begin{array}{l}\text { Kervancioglu et al. } \\
\text { (2011) }\end{array}$ & Fetus & 20 & 7 & 13 & 65 & 0 & 0 & 0 & 0 & 5 & 25 & 0 & 0 \\
\hline Leng et al. (2016) & Cadaver & 160 & 18 & 142 & 89 & 5 & 3 & - & - & 9 & 6 & - & - \\
\hline Present Study & Fetus & 50 & 8 & 42 & 84 & 1 & 2 & 1 & 2 & 4 & 8 & 2 & 4 \\
\hline
\end{tabular}

All the muscles in the anterior compartment of arm were supplied by the MCN with or without communications with the MN. Only when the MCN was absent, MN supplied all the muscles in the anterior compartment of arm. Other than that, there were no other nerves involved in the innervation of the muscles in the anterior compartment of arm or lateral cutaneous innervation of the forearm.

\section{CONCLUSION}

The study showed five possible courses of the MCN, with $16 \%$ of specimens within this study varying from the standard anatomical course. Knowledge of the variations of the MCN, including the communicating branch between $\mathrm{MCN}$ and MN, may assist medical practitioners as it may help the in diagnosis and treatment of peripheral nerve lesions, repair for trauma to the shoulder and in comprehending MCN dysfunction (Bhattarai \& Poudel; Ballesteros et al., 2015; Hayash et al., 2017 and Khake et al. 2018). These variations are also imperative for flap dissections, to elude iatrogenic neurological damage during surgical procedures of the arm and surgical neck of the humerus and post-traumatic evaluations of the arm (Bhattarai \& Poudel; Ballesteros et al.; Hayash et al., 2017; Khake et al.).This study recommends that further studies should be conducted on a larger sample size.

ACKNOWLEDGEMENTS. Dr. P Pillay is a University of KwaZulu-Natal (UKZN) Developing Research Innovation, Localisation and Leadership in South Africa (DRILL) fellow. DRILL, is a NIH D43 grant
(D43TW010131) awarded to UKZN in 2015 to support a research training and induction programme for early career academics. The content is solely the responsibility of the authors and does not necessarily represent the official views of DRILL and the National Institutes of Health.

KUPSAMY, K.; ISHWARKUMAR, S.; DE GAMA, B. Z. \& PILLAY, P. Clasificación del nervio musculocutáneo en fetos. Int. J. Morphol., 39 (2):653-658, 2021.

RESUMEN: El nervio musculocutáneo es un ram terminal del fascículo lateral del plexo braquial y está formado por las raíces espinales de C5, C6 y C7. Las variaciones anatómicas del nervio musculocutáneo (NMC) no son comunes, los informes literarios han descrito el curso diferente del NMC en el brazo, sin embargo, se han realizado muy pocos estudios fetales sobre las variaciones de este nervio. Por lo tanto, el objetivo del estudio fue describir el curso del NMC en fetos y documentar las variaciones. En este estudio, una muestra de veinticinco fetos fue disecada bilateralmente ( $\mathrm{n}=50)$ usando un estereomicroscopio. La anatomía del NMC se describió mediante un sistema de clasificación en base a los hallazgos. La aprobación ética se obtuvo del Comité de Ética en Investigación Biomédica (BE385 / 17). El tipo I (anatomía normal) del NMC se encontró en 42/50 (84\%) de las muestras. Se observaron algunas variaciones, por ejemplo: $1 / 50$ (2\%) caso de Tipo II (ausente), 1/50 (2\%) de Tipo III (comunicación entre NMC y nervio mediano (NM), de NM a NMC), 4/50 (8\%) casos de Tipo IV (comunicación del NMC al NM) y 2/50 (4\%) casos de Tipo V (comunicación del NMC al NM, donde el NMC no perfora el músculo coracobraquial). Este estudio proporciona evidencia de variaciones del NMC en fetos que puede ayudar a los cirujanos a interpretar patrones de inervación anormales en el brazo.

PALABRAS CLAVE: Nervio musculocutáneo; Estudio fetal; Clasificación; Variaciones anatómicas. 


\section{REFERENCES}

Ballesteros, L. E.; Forero, P. L. \& Buitrago, E. R. Communication between the musculocutaneous and median nerves in the arm: an anatomical study and clinical implications. Rev. Bras. Ortop., 50(5):567-72, 2015.

Besleaga, D.; Castellano, V.; Lutz, C. \& Feinberg, J. H. Musculocutaneous neuropathy: case report and discussion. HSS J., 6(1):112-6, 2010.

Bhattarai, C. \& Poudel, P. Unusual variation in musculocutaneous nerves. Kathmandu Univ. Med. J., 7:408-10, 2009.

Budhiraja, V.; Rastogi, R.; Asthana, A. K.; Sinha, P.; Krishna, A. \& Trivedi, V. Concurrent variations of median and musculocutaneous nerves and their clinical correlation--a cadaveric study. Ital. J. Anat. Embryol., 116(2):67-72, 2011.

Chauhan, R. \& Roy, T. Communication between the median and musculocutaneous nerve-a case report. J. Anat. Soc. India, 51:72-5, 2002.

Chitra, R. Various types of intercommunications between musculocutaneous and median nerves: An analytical study. Ann. Indian Acad. Neurol., 10(2):100-4, 2007.

Choi, D.; Rodríguez-Niedenführ, M.; Vázquez, T.; Parkin, I. \& Sañudo, J. R. Patterns of connections between the musculocutaneous and median nerves in the axilla and arm. Clin. Anat., 15(1):11-7, 2002.

Fazan, V. P. S.; Amadeu, A. S.; Caleffi, A. L. \& Rodrigues Filho, O. A. Brachial plexus variations in its formation and main branches. Acta Cir. Bras., 18(Suppl. 5):14-8, 2003.

Fregnani, J. H. T. G.; Macéa, M. I. M.; Pereira, C. S. B.; Barros, M. D. \& Macéa, J. R. Absence of the musculocutaneous nerve: a rare anatomical variation with possible clinical-surgical implications. São Paulo Med. J., 126(5):288-90, 2008.

Guerri-Guttenberg, R. A. \& Ingolotti, M. Classifying musculocutaneous nerve variations. Clin. Anat., 22(6):671-83, 2009.

Kervancioglu, P.; Orhan, M. \& Kilinc, N. Patterns of motor branching of the musculocutaneous nerve in human fetuses and clinical significance. Clin. Anat., 24(2):168-78, 2011.

Khake, S. A.; Tom, D. K. \& Belsare, S. M. Variations in branching pattern of musculocutaneous nerve with respect to communicating branch between musculocutaneous and median nerve. Int. J. Anat. Var., 11(3):77-80, 2018.

Krishnamurthy, A.; Nayak, S. R.; Venkatraya Prabhu, L.; Hegde, R. P.; Surendran, S.; Kumar, M. \& Pai, M. M. The branching pattern and communications of the musculocutaneous nerve. J. Hand Surg. Eur. Vol., 32(5):560-2, 2007.

Kwolczak-McGrath, A.; Kolesnik, A. \& Ciszek, B. Anatomy of branches of the musculocutaneous nerve to the biceps and brachialis in human fetuses. Clin. Anat., 21(2):142-6, 2008.

Le Minor, J. A rare variation of the median and musculocutaneous nerves in man. Arch. Anat. Histol. Embryol., 73:33-42, 1989.

Leng, L.; Liu, H.; Wang, T.; Liu, L. \& Si, D. Classifying musculocutaneous nerve variations depending on the origin. J. Neurol. Disord., 4(4):1000276, 2016.

Loukas, M. \& Aqueelah, H. Musculocutaneous and median nerve connections within, proximal and distal to the coracobrachialis muscle. Folia Morphol. (Warsz.), 64(2):101-8, 2005.

Moore, K. L.; Dalley II, A. F. \& Agur, A. M. Clinically Oriented Anatomy. 7th ed. Philadelphia, Wolters Kluwer Health/Lippincott Williams \& Wilkins, 2014.

Prasada Rao, P. V. \& Chaudhary, S. C. Communication of the musculocutaneous nerve with the median nerve. East Afr. Med. J., 77(9):498-503, 2000

Radunovic, M.; Vukasanovic-Bozaric, A.; Radojevic, N. \& Vukadinovic, T. A new anatomical variation of the musculocutaneous and the median nerve anastomosis. Folia Morphol. (Warsz.), 72(2):176-9, 2013.

Standring, S. Gray's Anatomy. The Anatomical Basis of Clinical Practice. 41st ed. Philadelphia, Elsevier, 2016.
Tank, P. W. \& Boileau Grant, J. C. Grant's Dissector. $14^{\text {th }}$ ed. Philadelphia, Wolters Kluwer/Lippincott Williams and Wilkins, 2009.

Venieratos, D. \& Anagnostopoulou, S. Classification of communications between the musculocutaneous and median nerves. Clin. Anat., 11(5):327-31, 1998.

\author{
Corresponding author: \\ Dr. P. Pillay \\ Department of Clinical Anatomy \\ School of Laboratory Medicine and Medical Sciences \\ College of Health Sciences \\ University of KwaZulu-Natal \\ Private Bag X54001 \\ Durban \\ 4000 \\ SOUTH AFRICA
}

E-mail: soobramoneypa@ukzn.ac.za

Received: 27-08-2020

Accepted: 29-10-2020 